\title{
PERDAMAIAN SEBAGAI PROSES RESOLUSI KONFLIK KELUARGA KRISTEN
}

\author{
Lourine Since Joseph \\ Institut Agama Kristen Negeri Ambon \\ inejoseph47@gmail.com
}

\begin{abstract}
Peace, tranquility, stability and happiness are the desires of human life, including Christian families. Consciously or not every individual in the life of a Christian family craves such a living situation. However, in fact, conflict is the reason for Christian families living in unhappiness, unease, unhappiness. Love and affection are lost due to the feeling and conviction that emerge as a way of life that is far from peaceful. Inner feelings and wounds outweigh the will of peace, stance exceeds the hope of living peacefully. Peace is one of the ways in the process of conflict resolution over conflicts that occur including Christian family conflicts. The way is through dialogue and communication with love and affection through conversation, dialogue with actions and attitudes, then the Christian family's peace is revealed.
\end{abstract}

Key words: peace, family conflict

\section{Pengantar}

Dalam kehidupan bersama di tengah masyarakat yang beragam sikap dan karak-teristik, tetapi juga beragam ide dan kepentingan serta identitas diri sebagai manusia yang bebas, maka banyak dijumpai benturan-benturan individu maupun kelompok masyarakat yang sangat berpengaruh dalam membangun kehidupan bersama di tengah keberagaman, budaya, agama, suku, dan terlebih beragam sikap dan karakter sebagai manusia yang sama dan sederajat. Sadar ataupun tidak konflik seperti menjadi bagian dari kehidupan manusia yang tidak dapat dihindari. Baik itu hubungan atau relasi yang kurang harmonis antara individu satu dengan individu lainnnya, maupun antar kelompok yang satu dengan kelompok lainnya.Konflik itu terjadi karena beragam alasan. Misalnya untuk sebuah kepentingan individu berkonflik, atau juga oleh karena perbedaan ide dan gagasan individu berkonflik, bahkan karena merasa diri kuat dari yang lain maka membuka peluang konflik itu terjadi.

Yang lebih parah lagi jika konflik itu disertai dengan kekerasan. Akar dari konflik itu sendiri berasal dari hawa nafsu manusia yang jahat dengan sejumlah keinginan dan harapan yang tidak tercapai yang juga berdampak pada hubungan yang tidak rukun dan damai.

Dampak serta akibat dari suatu konflik sangat beragam, misal-nya terpecahnya hubungan antar satu pribadi dengan pribadi lainya, bahkan juga merambas kepada terpecahnya hubungan kekeluargaan dalam lingkungan bermasyarakat. Issue sentral yang lebih banyak disuarakan oleh manusia di saman ini adalah konflik keluarga Kristen yang berakhir dengan pisah ranjang sampai pada perceraian.Konflik-konflik tersebut dalam skala yang besar bahkan sampai pada kekerasan fisik selalu diupayakan penanganannya, namun yang tidak dapat dihindari adalah luka batin yang sulit dihilangkan. Hal yang sangat memprihatinkan adalah konflik-konflik tersebut lebih banyak lahir dari keluarga Kristen yang gagal menerjemahkan pentingnya membangun perdamaian dalam kehidupan keluarga, dengan jalan menunjukan cinta dan kasih sayang diantara sesama anggota keluarga, walaupun ada banyak persoalan atau permasalahan yang terjadi dan sulit untuk diatasi.

Fenomena empiris permasalahan keluarga Kristen saman ini, termasuk di beberapa Jemaat di klasis pulau Ambon,terjadi lebih banyak karena masalah ekonomi keluarga, kebutuhan pendidikan anak-anak yang cukup besar, relasi social yang berlebihan seperti pergaulan yang melebihi batas kemanusiaan, perselingkungan, seks bebas, bahkan ada juga merasa jenuh dengan pasangannya, sehingga peluang terjadinya konflik cukup besar yang akhirnya berdampak pada relasi sosial keluarga Kristen menjadi hancur. Hal itu nyata dari hasil penelitian, ada suami meninggalkan istri,sebaliknya istri meninggalkan suami, anak meninggalkan rumah, karena hilang arah untuk memilih jalan akibat konflik orang tua, bahkan sampai pada tingkat perceraian dalam usia pernikahan yang masih muda. Fakta empiris inilah membuka ruang hati setiap pemerhati keluarga dan juga pemerhati anak untuk menyuarakan perdamain dan pembebasan sebagai bagian dari sebuah resolusi 
konflik atas konflik-konflik yang dialami keluarga Kristen saat ini.

\section{Tinjauan Literatur Konflik Dan Sebab-Sebabnya}

Konflik merupakan fenomena yang sering terjadi di dalam masyarakat, termasuk juga keluarga, organisasi maupun antar pribadi. Alasan dan dinamika terjadinya konflik sangatlah beragam. Menurut Pneuman Roy dalam Jois, 1982, Secara etimologi, konflik berasal dari bahasa Latin, yakni 'Fligere' yang berarti menyerang, 'To strike ' dan 'com' yang berarti bersama-sama (Jois.A.Rantung, 2017). Kata kerja bahsa Latin untuk konflik, yakni' configure' kemudian diadopsi kedalam Bahasa Inggris, menjadi 'conflict.' Jadi konflik dapat dimengerti sebagai suatu tindakan yang saling menyerang atau secara bersam-sama saling menyerang.

Menurut kamus besar Bahasa Indonesia, konflik didefinisikan sebagai percekcokan, perselisihan atau pertentangan. Bila lebih diperinci lagi menurut klasifikasi , konflik yang ditinjau dari segi batin, konflik tersebut disebabkan oleh adanya dua gagasan atau lebih keinginan yang saling bertentangan untuk menguasai diri sehingga memengaruhi tingkah laku. Bilamana dilihat dari segi kebudayaan, konflik dipahami sebagai akibat persaingan anatar dua masyarakat sosial yang mempunyai kebudayaan hampir sama. Bilamana dilihat dari segi social, konflik adalah pertentangan antara anggota masyarakat yang bersifat menyeluruh. Konflik juga merupakan gejala psikologis, yang umumnya mengiing individu pada suasana kurang menguntungkan terutama jika tidak mengatasinya.(Gunaryo Achmad, 2007) Konflik yang dimaksudkan dari penulisan ini, adalah lebih banyak melihat pada konflik batin yang melanda kehidupan keluarga Kristen yang berdampak pada hilangnya rasa damai di hati, penindasan terhadap diri sendiri bahkan orang lain yang menjadikan individu keluarga tidak merasakan sebuah pembebasan dalam realitas kehidupan keluarga.

\section{Penyebab Konflik}

Terjadinya konflik dalam realitas kemanusiaan manusia, disebabkan oleh paling sedikit empat hal yaitu (Gunaryo Achmad. 2007):
1. Adanya perbedaan individu.

Perbedaan ini, meliputi perbedaan perasaan, dan pendirian. Sadar atau tidak setiap individu manusia memiliki pendirian dan perasaan yang berbeda satu dengan lainnya.Perbedaan ini-lah yang membuka ruang terjadinya konflik, jika tidak dilihat sebagai sebuah kekayaan untuk saling berbagi dan melengkapi.Pernyataan ini, jika dihubungankan dengan konflik batin individu, tentunya melibatkan rasa batin jika masing-masing individu mempertahankan pendirian dan ego diri yang akhirnya tidak kunjung berhenti. Setiap individu manusia memiliki rasa atas setiap kondisi dan situasi social yang dihadapi. Apalagi jika situasi sosial itu membuat dirinya tidak bebas dan damai menghadapi kehidu-pannya di tengah keluarga, bahkan lingkungan dimana individu itu berada. Dengan pendiriannya individu akan berusaha mencari ketenangan batinnya, rasanya yang menurutnya adalah jalan terbaik atas realitas hidup yang dialami. Namun, terkadang jalan yang ditempuh atau dipilih tidak menjadi solusi akhir memecahkan masalah sosial kehidupan individu, apalagi di tengah keluarga.

\section{Perbedaan Latar Belakang Kebudayaan.}

Indonesia adalah Negara yang majemuk, baik dari segi agama, sosial maupun budaya.Ini adalah kekayaan yang menjadi kekuatan untuk mengembangkan Indonesia kearah masyara-kat sejahtra dan damai. Hal tersebut dapat saja diterima jika keberagaman itu dipakai sebagai kekayaan bangsa untuk saling melengkapi satu dengan lainnya. Apalagi di tengah kehidupan keluarga, dimana setiap individu yang lahir dan dipersatukan dalam ikatan perkawinan, adalah individu yang berbeda budayanya, karakternya, juga rasa dan pendirian seperti yang telah diuraikan sebelumnya. Perbedaan budaya itu jika tidak dilihat secara baik akan membuka peluang untuk terjadinya konflik. Masingmasing individu mempertahankan nilai-nilai budanya, yang berdampak pada konflik rasa akibat prinsip diri atau pendirian yang tidak dapat berubah.

\section{Perbedaan Kepentingan.}

Jika dalam realitas sosial kehidupan manusia, ada punya kepentingan diri, atau juga kelompok, maka membuka kesempatan penuh terjadiya konflik. Demikian halnya juga dalam keluarga.Masing-masing individu jika punya 
kepentingan dibalik setiap situasi sosial keluarganya, maka besar peluang terjadinya konflik, baik antar ayah dan ibu, maupun anakanak. Kadang-kadang ada individu yang melakukan hal yang sama untuk tujuan yang berbeda.

\section{Perubahan Nilai Yang Cepat Dan Mendadak.}

Misalnya dalam hal kepercayaan dan tangungjawab. Jika seseorang individu diberikan kepercayaan dan tanggungjawab untuk mengatur kehidupan keluarga, atau organisasi atau persekutuan, dan secara mendadak ada perubahan kepercayaan dan tanggungjawab itu kepada individu lain, maka sangat berdampak terjadinya konflik. Hal tersebut mungkin saja karena rasa batin yang terganggu atau juga prinsip diri yang tidak ingin berubah. (Gunaryo Achmad, 2007)

Konflik memang tidak dapat dihindari dalam kehidupan manusia baik sengaja maupun yang diatur atau dibuat dengan berbagai cara. Konflik juga dapat dilihat sebagai suatu konsekuensi dari komunikasi yang buruk, salah pengertian, salahperhitungan, yang disertai proses-proses lain yang tidak disadari. Oleh karena itu, menurut Watkins sebagaimana dikutip oleh Robby Candra, sebab-sebab suatu konflik terjadi, jika terdapat dua pihak yang secara potensial dan praktis, dapat saling menghambat(Robby Candra, 1992). Secara potensial mereka memiliki kemampuan untuk menghambat dan secara praktis operasional, kemampuan itu dapat diwujudkan dalam keaadaan yang memungkinkan perwujudannya secara mudah. Konflik dapat juga terjadi jika ada sasaran yang sama-sama dikejar oleh kedua pihak yang menjadi tujuan. Andar Ismailmenjelaskan, kecendrungan konflik itu terjadi karena seseorang atau kelompok orang sering memaksakan, kehendak, yakni, keinginanku, pendapatku, usulku, rencanaku, caraku, kebutuhanu, aspirasiku, gagasanku, konsepku, dan sebagainya. Konflik di sini adalah konflik yang berhubungan dengan kepribadian seseorang yang memaksakan kehendak pribadiya yang belum tentu sejalan dengan orang lain, atau pihak lain. Dengan katalain konflik itu terjadi karea hawa nafsu manusia yang jahat (Andar Ismail, 2002). Sebab lain juga adalah prasangka-prasangka atau desas-desus. Ini adalah sikap yang tidak baik, dan dapat menggangu, sebab dianggap sebagai suatu predisposisi untuk persepsi, berpikir, merasa dan bertindak. (Abu Ahmadi, 2010)

\section{Hasil \\ Konsep DasarPerdamaian.}

Damai, adalah sebuah istilah yang berhubungan erat dengan pemakaian dalam bahasa Latin pacem dari akar kata pacification atau pacificare yang berarti penyelenggaraan perdamaian atau pendamaian. Istilah tersebut juga dihubungkan dengan perjanjian damai. Pemakaian istilah 'damai' menunjukan(R.M.Drie Brotosudharmo, 2008) pada keadaan tanpa konflik. Istilah perdamaian juga erat hubungannya dengan istilah dalam bahasa Inggris, atonement. Istilah ini berakar dari suatu kondisi atone sesudah terjadi perpisahan. Dalam bahasa Yunani disebut katallage yang berarti pendamaian kembali. Intinya lebih mengarah pada perdamaian menuju perubahan sikap.(R.M.Drie Brotosudharmo, 2008)

Wajah lain dari konflik adalah perdamaian. Damai adalah suatu keadaan atau suatu kondisi masyarakat yang ditandai dengan ketidakadaan kekerasan dalam bentuk apapun, baik fisik, psikhis, intimidasi, prasangka, diskriminasi atau juga kekerasan. Hadirnya dialog sebagai gaya hidup yang melahirkan sikap saling menghormati dan memahami terhadap perbedaan yang ada, terwujudnya hubungan dan kerjasama demi kebaikan bersama.(Yusuf Asri, 2013). Yusuf juga mengatakan bahwa damai bukanlah suatu keadaan atau situasi yang statis hening, dan senyap tanpa dinamika. Justru masyarakat yang dinamis, adalah masyarakat yang senantiasa menjadikan dialog sebagai metode dalam menjawab berbagai persoalan dalam masyarakat, termasuk konflik dalam keluarga. Oleh karena itu perdamaian tidak pernah muncul atau jatuh dari langit, tetapi hasil usaha yang mesti diperjuangkan oleh individu, kelompok atau masyarakat secara bersama-sama dan terus menerus.

\section{Keluarga Kristen}

Keluarga Kristen adalah pem-berian Tuhan yang tidak ternilai harganya. Keluarga Kristenlah yang memegang peranan terpenting dalam membangun perdamaian di tengah realitas hidup keluarga ketika ada persoalan, baik suami-istri orang tua dan anak. Bahkan yang lebih penting pula dari segala jalan yang dilakukan oleh gereja untuk sebuah perdamaian melalui pendidikannya. Pada umumnya, keluarga sangat besar nilainya bagi manusia. Ilmu sosiologi menjunjung keluarga 
sebagai satuan pokok bagi seluruh masyarakat termasuk keluarga Kristen.Jika keluarga kukuh dan sehat, maka masyarakat juga demikian.

Keluarga adalah satu persekutuan yang terdiri dari orang-orang yang saling terikat oleh ikatan darah dan perhubungan sosial yang paling rapat. Baik orang tua maupun anak-anak memperoleh berkat rohani besar di dalam keluarga yang dipimpin oleh Roh Tuhan.Apabila keluarga disucikan dan dikuduskan oleh Yesus Kristus, niscaya keluarga itu menjadi taat dan kuat di dalam tangan Tuhan untuk memperkembangkan dan mematangkan pribadipribadi Kristen yang luhur.(I.H.Enklaar dan E.G.Homrighausen, 2011)

Itu berarti keluarga Kristen merupakan suatu persekutuan anatar anak-anak dengan ayah-ibunya, dengan keluarga besar lainnya yang sanggup menciptakan suasana Kristen sejati di dalam lingkungan mereka sendiri. Yang menjadi anggota persekutuan dengan Kristus itu tertambat satu sama lain oleh kasih Kristus. Segala gerak-gerik, sikap hidup akan ditentukan oleh kepercayaan dan pengalaman Kristen mereka di bawah pengawasan Tu-han sendiri. Semua masalah dan kesulitan yang timbul dalam terang Injil Kristus. Segala pergaulan hidup rumah tangganya diserahkan pada pimpinan Roh Kudus. (I.H.Enklaar dan E.G.Homrighausen, 2011)

Keluarga Kristen adalah bayangan dari Gereja bahkan dari kerajaan Allah. Sepanjang sejarah umat manusia, keluarga Kristen selalu diperhadapkan dengan masalah yang mengancam keutuhan hidup. Seteru yang paling kuat di dalam keluarga Kristen adalah kemunduran kesetiaan suami-istri satu sama lain. Pertalian nikah mulai renggang, mutu kesusilaan dalam keluarga Kristen merosot.Betapa banyak nikah Kristen dinodai dengan percekcokan atau perkelahian, kepentingan anak tidak lagi menjadi hal penting, dan sering memutuskan saja perhubungan nikah sehingga anakanak menjadi korban. (I.H.Enklaar dan E.G.Homrighausen, 2011)

\section{Perdamaian Sebagai Proses Revolusi Konflik Keluarga Kristen.}

Budaya damai selalu menjadi kerinduan umat, termasuk dida-lamnya keluarga Kristen. Mengapa, karena dengan hidup damai, maka setiap individu manusia merasakan kebebasannya sebagai ciptaan Allah, membangun hidup bersama yang rukun dan damai, solidaritas diantara sesama dalam hidup keluarga. Hal ini sejalan dengan pernyataan beberapa keluarga dalam hasil penelitian yang menjelaskan bahwa dalam kehidupan keluarga Kristen, hal utama yang menjadi dambaan adalah terciptanya kehidupan keluarga yang damai, rukun, saling menerima kelebihan dan kekurangan serta saling menghormati diantara anggota keluarga. Ada kecocokan, tidak menciptakan suasana jenuh satu terhadap lainnya. Dengan kata lain jangan ada konflik. Hal ini menunjukan bahwa dalam perjalanan kehidupan keluarga Kristen, konflik tetap menjadi bagian kehi-dupan manusia, namun sejauh konflik itu dapat diatasai secara damai maka kehidupan keluarga Kristenpun akan hidup dalam kedamaian dan kebahagiaan. Persoalannya, bagaiamana konflik keluarga Kristen teratasi.Apakah resolusi konflik mampu menawarkan jalan perdamaian bagi keluarga Kristen.

Menurut beberapa ahli pendidikan agama, berpendapat bahwa, perdamaian adalah sebuah proses resolusi konflik yang mentransformasikan nilai-nilai hidup kebersamaan yang damai, rukun, cinta dan kasih sayang. Jika salah satu individu terlibat konflik yang salah, maka individu lainnya harus dapat memaafkan.Kedua pihak yang terlibat konflik dapat saling memaafkan. Andar Ismail dalam bukunya Selamat Sejahtera mendeskripsikan bahwa perdamaian itu adalah lepas dari rasa takut, khawatir, gelisah, marah, curiga, dendam, iri hati bahkan sakit hati. Jika sikap ini dapat dikendalikan dengan menunjukan sikap damai sebagai proses resolusi konflik, maka keluarga Kristen menjadi gambaran keluarga Allah yang sejati, sebuah gambaran kerajaan Allah yang damai dan tenang.Damai adalah ketenangan batin, rasa tentram dan sejahtera.Damai adalah harmoni dan kerjasama.Damai adalah kenyataan di mana setiap individu dalam keluarga mengalami keadilan, dan kewajaran. Damai adalah upaya atau proses memecahkan konflik termasuk juga konflik keluarga Kristen. Persoalannya, bagaimana perdamaian itu diwujudkan sebagai proses resolusi konflik keluarga Kristen atas pertanyaan ini, penjelasan informan dalam penelitian bahwa, dialog dan komunikasi dalam cinta dan kasih sayang adalah jalan sebuah perdamaian. Keluarga perlu mencip-takan dan membangun kembali relasi dan hubungan yang dulu 
damai dan harmonis, untuk menumbuhkan kesadaran sebuah perdamaian sejati bagi keluarga. Melalui dialog ada keterbukaan diantara satu dengan lainnya, tidak saling curiga, cemburu, dendam dan iri hati satu terhadap lainnya.

Brothosudarmo mengungkap dialog dapat dilakukan dalam bentuk percakapan secara terbuka, dialog dalam tindakan, untuk saling terbuka, saling belajar, saling memberi, dan bertumbuh bersama untuk menciptakan harmoni dan kesejatraan keluarga. Dasar dari dialog itu adalah kesadaran akan hidup bersama, seperti yang dikehendaki oleh Tuhan Allah di dalam Yesus Kristus yang datang menjumpai manusia demi perda-maian manusia dengan Allah. Manusia dapat saling berdamai, jika ia mampu berjumpa dengan sesa-manya anggota di dalam keluarga secara damai. Hal itu akan memulihkan konflik yang terjadi diantara sesame angota keluarga Kristen. Hakikat manusia adalah menolak sikap berdiam diri, termasuk juga keluarga Kristen. Konflik keluarga Kristen, tidak dapat terselesaikan dengan berdiam diri, tetapi berelasi, berkomunikasi, belejar bersama dan memaknai hidup keluarga Kristen sebagai bagian dari kasih karunia Allah yang mendamaikan dan membebaskan.

\section{Simpulan}

Jangan pernah menjadikan konflik sebagai pemicu hilangnya perdamaian, tetapi mari jadikan konflik sebagai alat untuk lebih mempererat rasa cinta damai baik bagi keluarga Kristen secara khusus dan keluarga secara umum

\section{Saran Dan Rekomendasi}

Demikian tulisan tentang Perdamaian Sebagai Proses Resolusi Konflik Keluarga Kristen ini dibuat, dengan harapan semoga dapat bermanfaat bagi keluarga-keluarga Kristen masa kini maupun masa depan untuk tidak menjadikan konflik sebagai pemicu hilangnya perdamaian bagi keluarga Kristen secara khusus, dan keluarga secara umum.

\section{Ucapan Terima Kasih}

Pada kesempatan ini, penulis mengucapkan terima kasih kepada Redaktur yang telah memberikan masukan yang berharga sehingga tulisan dapat diterbitkan di Jurnal Institutio. Terima kasih juga kepada pengurus jurnal Institutio yang telah memberi ruang diskusi.
Penulis tidak dapat membalas semuanya, hanya doa yang tulus semoga segala kebaikan yang penulis dapatkan, dibalas oleh Tuhan dengan berkat kehidupan bagi kita semua.

\section{Pustaka Acuan}

Andar Ismail, 2002, Selamat Sejahtera, Jakarta; BPK Gunung Mulia.

Abu Ahmadi, 2010, Psikologi Sosial, Surabaya;Bina Ilmu

Departemen Pendidikan Dan Kebudayaan , Kamus Besar Bahasa Indonesia -edisi ke 3, Jakarta; Balai Pustaka,

Gunaryo Achmad. 2007. Konflik DanPendekatan Terhadapnya, dalam M. Muchsin Jamil, Mengelola Konflik, membangun damai. Semarang; Walisogo, Mediator Center.

I.H.Enklaar dan E.G.Homrighausen, 2011, Pendidikan Agama Kristen, cet ke 25, Jakarta; Gunung Mulia

Jois.A.Rantung. 2017. Resolusi Konflik Dalam Organisasi, Jakarta; BPK.Gunung Mulia,

Robby Candra, 1992, Konflik Dalam Kehidupan Sehari-Hari, Jakarta; Kanisius,

R.M.Drie Brotosudharmo, 2008. PAK Untuk Perguruan Tinggi, Yokjakarta;Andi

Yusuf Asri, 2013, Masyarakat Membangun Harmoni Resolusi Konflik Dan Bina Damai, Jakarta; Pustlitbang Kehidupan Beragama 